\title{
Operational strategies for long-term biohydrogen production from sugarcane stillage in a continuous acidogenic packed-bed reactor
}

\author{
Lucas Tadeu Fuess ${ }^{a, *}$, Luma Sayuri Mazine Kiyuna ${ }^{a}$, \\ Marcelo Loureiro Garcia ${ }^{b}$, Marcelo Zaiat ${ }^{a, c}$ \\ a Biological Processes Laboratory (LPB), São Carlos School of Engineering (EESC), University of São Paulo (USP), \\ 1100 João Dagnone Avenue, 13563-120 São Carlos, SP, Brazil \\ ${ }^{\mathrm{b}}$ Institute of Geosciences and Exact Sciences, UNESP - Univ Estadual Paulista, 1515 24-A Avenue, 13506-900 Rio \\ Claro, SP, Brazil \\ ${ }^{\mathrm{c}}$ Brazilian Bioethanol Science and Technology Laboratory (CTBE), Brazilian Center for Research in Energy and \\ Materials (CNPEM), 10000 Giuseppe Máximo Scolfaro Street, 13083-970 Campinas, SP, Brazil
}

\section{A R T I C L E I N F O}

Article history:

Received 5 August 2015

Received in revised form

3 October 2015

Accepted 7 October 2015

Available online 22 December 2015

Keywords:

Continuous biohydrogen production

Long-term operation

Operational strategies

Sugarcane stillage

\begin{abstract}
A B S T R A C T
The use of packed-bed reactors for biohydrogen production often results in performance losses in the short term because of the negative effects of operational factors, such as biomass accumulation and inadequate $\mathrm{pH}$ conditions. Because packed-bed systems constitute a promising technology for biohydrogen production, studies on continuous hydrogen production over the long term must be carefully conducted by applying proper operational strategies. Therefore, this study assessed continuous biohydrogen production in a packed-bed reactor operated under thermophilic conditions $\left(55^{\circ} \mathrm{C}\right)$ using sugarcane stillage as the substrate. The results indicated that the acidogenic reactor presented a capacity for recovering from performance losses, regardless of their cause, and maintaining continuous hydrogen production rates under long-term operation (240 days). $\mathrm{pH}$ proved to be a key factor for obtaining continuous hydrogen production, and the optimal results were observed in a $\mathrm{pH}$ range from 5.1 to 5.2. Furthermore, an optimal specific organic loading rate of 6.3-6.4 g carbohydrates $\mathrm{g}^{-1}$ volatile suspended solids $\mathrm{d}^{-1}$ was observed, and this value is consistent with the results of previous studies focused on hydrogen production from fermentative systems.
\end{abstract}

() 2015 Hydrogen Energy Publications LLC. Published by Elsevier Ltd. All rights reserved.

\section{Introduction}

Hydrogen production using dark fermentation constitutes an attractive approach for the generation of bioenergy because it has the potential to achieve important advantages over conventional electro- and thermochemical approaches, including low energy consumption that generates a positive energy balance, low production costs, the potential reuse of wastewaters and residues as carbon sources, the potential production of value-added metabolites (e.g., organic acids, ethanol and butanol) and biopolymers and high biohydrogen

\footnotetext{
* Corresponding author. Tel.: +55 (16) 33738360.

E-mail addresses: ltfuess@sc.usp.br (L.T. Fuess), luma.kiyuna@usp.br (L.S. Mazine Kiyuna), mlgarcia@rc.unesp.br (M.L. Garcia), zaiat@ sc.usp.br (M. Zaiat). 
$\left(\mathrm{BioH}_{2}\right)$ yields relative to light-dependent processes [1-3]. Using hydrogen as an energy carrier presents additional advantages because hydrogen has a high heating value and water vapor is the sole residue generated from combustion; thus, it leads to zero emissions of greenhouse gases [3].

The literature describes the use of several types of wastewaters as substrates in fermentative reactors, such as cheese whey [4,5], soft-drink wastewater [2], food processing and dairy wastewater [5-7], beet molasses [8], and tequila, cassava and corn stillages $[1,9,10]$. Some recent studies on $\mathrm{BioH}_{2}$ production have also assessed the use of sugarcane stillage [11-16], characterized as the main wastewater from ethanol production [17]. $\mathrm{BioH}_{2}$ production from sugarcane stillage may be a feasible technological approach because this wastewater has an appreciable residual content of carbohydrates, the main substrate assimilated by hydrogen-producing bacteria (HPB). Although certain operational conditions have been tested, such as different dilution rates [14] and organic loading rates [11,15], the literature lacks reports on the efficient utilization of sugarcane stillage in fermentative systems, especially when continuous $\mathrm{BioH}_{2}$ production is intended over the long term.

Studies on continuous fermentative systems are usually conducted in continuously stirred tank reactors (CSTRs) $[8,10,18]$, based on the simple operational and controlling features of such reactors. However, in suspended-cell reactors, differentiation is not observed between the solids retention time (SRT) and the hydraulic retention time (HRT), thus leading to low cell densities and limiting the contact time between the biomass and the substrate [19]. On the contrary, systems such as anaerobic packed-bed reactors (APBRs) concentrate important advantages because they can utilize higher SRTs $[4,20]$. However, several studies have indicated unstable and often decreasing $\mathrm{BioH}_{2}$ production in acidogenic packed-bed systems within 50-60 days of operation, regardless of the wastewater type and temperature conditions [12,21-23].

In the literature, performance losses in acidogenic systems are usually associated with inadequate operational conditions, such as the excessive accumulation of biomass in the reactors $[2,24,25]$, inadequate $\mathrm{pH}$ conditions $[5,26,27]$ and the application of organic under- or overloads [11,14-16,28]; thus, it may be possible to obtain continuous hydrogen production rates by applying the proper operational strategies to the reactors. With respect to $\mathrm{pH}$, most of the associated studies have focused on the influence of the initial $\mathrm{pH}$ on $\mathrm{BioH}_{2}$ production without properly controlling the effluent $\mathrm{pH}[5,26]$. Acidogenic systems characterized by effluent $\mathrm{pH}$ variations are vulnerable to performance losses because of factors that depend strictly on the $\mathrm{pH}$ conditions provided to the microorganisms, such as hydrogenase activity, metabolic pathways and cell flocculation and adherence phenomena $[5,26]$. The excessive accumulation of biomass impacts the specific organic loading rate (SOLR), which roughly represents the food-to-microorganism ratio applied to the reactor. In short, excessive solids concentrations may promote substrate shortages and stimulate homoacetogenic bacteria to consume molecular hydrogen [12,22,25]. Additional limitations produced by the accumulation of solids include the establishment of high hydrogen partial pressures within the packed bed, which also leads to metabolic shifts, based on increased production of more reduced compounds, such as propionic and butyric acids [29-32]. Finally, studies on continuous $\mathrm{BioH}_{2}$ production from acidogenic systems are usually based on the application of increasing organic loading rates (OLRs) as a strategy to prevent performance losses $[4,24,33]$. However, this strategy may lead to conditions of organic overload because excessive concentrations of substrate may be introduced over relatively low HRTs. Studies on $\mathrm{BioH}_{2}$ production from stillage have frequently reported the accumulation of organic acids, especially propionic and butyric acids, in acidogenic systems submitted to OLR conditions that are usually higher than $100 \mathrm{~kg}$ COD m $\mathrm{m}^{-3} \mathrm{~d}^{-1}[14-16,28]$. Moreover, in a previous study, Ferraz Jr. et al. [11] mathematically determined an optimal OLR of $84.2 \mathrm{~kg} \mathrm{COD} \mathrm{m}^{-3} \mathrm{~d}^{-1}$ for $\mathrm{BioH}_{2}$ production from sugarcane stillage under thermophilic conditions; therefore, the continuous application of this OLR in a long-term operation should be investigated.

Studies on long-term $\mathrm{BioH}_{2}$ production from real wastewaters are of great interest to identify the influence of both wastewater compositional variations and biomass aging over the hydrogenogenic activity. Regarding specifically sugarcane stillage, Santos et al. $[15,16]$ continuously operated anaerobic fluidized-bed reactors (AFBRs) for 150 days and 120 days, whereas Santos et al. [14] employed an operating period of 308 days for an AFBR fed mixtures of stillage and glucose. However, the stillage was usually diluted prior to feeding the reactors, and increasing OLR conditions were always employed. With respect to $\mathrm{BioH}_{2}$ production from packed-bed reactors treating stillage, a single report indicated the operation of an APBR for only 60 days under thermophilic conditions [12]; thus, the potential of the system to recover from performance losses could not be properly assessed. Moreover, the literature does not provide sufficient information on the dynamics of hydrogen production from sugarcane stillage in packed-bed reactors under long-term operations.

Therefore, this study assessed the long-term production of $\mathrm{BioH}_{2}$ from an upflow acidogenic APBR continuously operated under thermophilic conditions $\left(55^{\circ} \mathrm{C}\right)$ using raw sugarcane stillage as the substrate. The reactor was operated throughout the sugarcane season (approximately eight months), and different operational strategies were applied to the APBR, including the [i] application of a high and continuous organic loading rate, [ii] pH control of the effluent of the reactor, and [iii] periodic discharge of excessive biomass. Hydrogen production as assessed by the volumetric hydrogen production rate (VHPR) and hydrogen yield (HY) was also correlated with different parameters, including the effluent $\mathrm{pH}$ and specific organic loading rate, to identify the optimal ranges for the operation of packedbed systems. This study may be considered the first approach to assessing the long-term production of $\mathrm{BioH}_{2}$ from raw sugarcane stillage under long-term operations, such as over a complete sugarcane season, regardless of the type of reactor.

\section{Materials and methods}

\section{Stillage characterization}

Sugarcane stillage samples were regularly collected from a full-scale ethanol and sugar plant located in Pradópolis, Sao Paulo State (SP), Brazil. The sampling was conducted throughout the entire sugarcane season, and the main 
physicochemical characteristics of the stillage included the total chemical oxygen demand (TCOD) $-28.3 \pm 4.6 \mathrm{~g} \mathrm{~L}^{-1}$; soluble chemical oxygen demand (SCOD) $-22.9 \pm 4.0 \mathrm{~g} \mathrm{~L}^{-1}$; biochemical oxygen demand (BOD) $-14.6 \pm 3.5 \mathrm{~g} \mathrm{~L}^{-1}$; BOD/ TCOD ratio $=0.51 \pm 0.07$; total soluble carbohydrates $(\mathrm{CH})-$ $5.6 \pm 1.3$ g-sucrose $\mathrm{L}^{-1}$; total phosphorus $-113 \pm 105 \mathrm{mg} \mathrm{L}^{-1}$; total Kjeldahl nitrogen $-862 \pm 219 \mathrm{mg} \mathrm{L}^{-1}$; volatile suspended solids (VSS) - $818 \pm 223 \mathrm{mg} \mathrm{L} \mathrm{L}^{-1}$; sulfate $\left(\mathrm{SO}_{4}^{2-}\right)-$ $1700 \pm 430 \mathrm{mg} \mathrm{L}^{-1}$; and $\mathrm{pH}-4.5 \pm 0.1$. The different sampling periods (C1 to $\mathrm{C6} / 7$ ) are properly indicated in the figures. Stillage was filtered through a $3 \mu \mathrm{m}$ paper filter (Nalgon Equipamentos Científicos, Itupeva, SP, Brazil, density of $80 \mathrm{~g} \mathrm{~m}^{-2}$ ) prior to feeding the reactor to remove excessive levels of suspended solids and avoid clogging the reactor. TCOD corresponds to the organic matter concentration of the filtered samples.

\section{Reactor design and operational conditions}

A bench-scale $(2.3 \mathrm{~L}$ ) acidogenic APBR was operated for 240 days, which corresponds to the average duration of the sugarcane season in Brazil. Constructive aspects of the reactor as well as characteristics of the experimental apparatus are depicted in Fig. 1. Low-density polyethylene (LDPE) was used as the support material because previous studies on stillage fermentation [11-13] indicated that LDPE as an adequate media for $\mathrm{BioH}_{2}$ production. The $\mathrm{pH}$ of the stillage was adjusted to between 5.5 and 7.5 using a solution of sodium hydroxide $(\mathrm{NaOH}) 50 \% \mathrm{w} / \mathrm{V}$. The initial $\mathrm{pH}$ of the feeding stream was set according to the $\mathrm{pH}$ measured in the acidified stillage to provide optimal conditions to enhance $\mathrm{BioH}_{2}$ production. The reactor was inoculated using the natural fermentation of stillage according to the protocol previously described by Leite et al. [34].

The reactor was operated in a controlled temperature chamber $\left(55^{\circ} \mathrm{C}\right)$ and continuously fed with filtered stillage using a peristaltic pump (Model Minipuls Evolution, Gilson Inc., Middleton, WI, USA). The use of thermophilic conditions in anaerobic reactors applied to stillage is a suitable approach because stillage is generated at high temperatures $\left(90-100^{\circ} \mathrm{C}\right)$. Moreover, a higher hydrogen-production potential has been reported for thermophilic systems compared with the mesophilic ones $[18,31,35]$. The OLR was set at $84.2 \mathrm{~kg} \mathrm{COD} \mathrm{m}^{-3} \mathrm{~d}^{-1}$ (HRT of $7.5 \mathrm{~h}$ ), which was mathematically defined as the optimal OLR for the thermophilic hydrogen production of sugarcane stillage [11]. An increase was applied in the OLR ( $110 \mathrm{~kg}$ COD $\mathrm{m}^{-3} \mathrm{~d}^{-1}$, HRT of $6 \mathrm{~h}$ ) over a short-term period (days 160-165) in an attempt to improve the hydrogenogenic activity of the reactor; subsequently, the OLR was reduced to $84.2 \mathrm{~kg} \mathrm{COD} \mathrm{m} \mathrm{m}^{-3} \mathrm{~d}^{-1}$.

\section{Performance evaluation: analytical methods}

The performance of the reactor was assessed based on measurements of the following parameters: $\mathrm{pH}$, VSS, total soluble $\mathrm{CH}$, volatile fatty acids (VFAs) and solvents levels. The values of $\mathrm{pH}$ and VSS were obtained according to the procedures described in the Standard Methods for the Examination of Water and Wastewater [36]. Total $\mathrm{CH}$ levels were determined according to the phenol-sulfuric method proposed by Dubois et al. [37] so that absorbance measurements were conducted at $490 \mathrm{~nm}$ using a sucrose standard curve (20-180 mg-sucrose $\mathrm{L}^{-1}$ ). The curve was prepared by diluting a standard solution of sucrose $1 \% \mathrm{~m} / \mathrm{v}$. VFA (acetic, propionic, butyric, isobutyric, valeric, isovaleric and caproic acids) and solvents (methanol, ethanol, n-butanol) were analyzed by gas chromatography with a flame ionization detector (GC-FID) according to the protocol described by Adorno et al. [38]. The biomass yield coefficient $\left(\mathrm{Y}_{\mathrm{X} / \mathrm{S}}\right.$, in $\mathrm{g}$ VSS $\left.\mathrm{g}^{-1} \mathrm{CH}\right)$, the biomass percentage retained in the reactor and the SOLR $\left(\mathrm{g} \mathrm{CH} \mathrm{g}^{-1} \mathrm{VSS} \mathrm{d}^{-1}\right.$ ) were calculated at the end of the operating period, as proposed by Anzola-Rojas et al. [25].

The biogas flow rate was measured with a gas meter model MGC-1 V30 (Ritter ${ }^{\circledR}$ ). The biogas composition (hydrogen, carbon dioxide and methane) was determined with a GC 2010 (Shimadzu Scientific Instruments, Columbia, MD, USA) equipped with a thermal conductivity detector (TCD) using argon as the carrier gas and a CARBOXEN 1010 Plot column (30 $\mathrm{m}, 0.53 \mathrm{~mm})[4]$.

The response variables used to assess the performance of the reactor included the conversion of total $\mathrm{CH}\left(\mathrm{EC}_{\mathrm{CH}}\right.$, in \%), biogas flow rate (BFR, in $\mathrm{mL} \mathrm{d}^{-1}$ ), volumetric hydrogen production rate (VHPR, in $\mathrm{mL} \mathrm{H}_{2} \mathrm{~L}^{-1} \mathrm{~d}^{-1}$ ), molar hydrogen flow rate (MHFR, in mmol $\mathrm{H}_{2} \mathrm{~h}^{-1}$ ), hydrogen yield ( $\mathrm{HY}$, in $\mathrm{mol} \mathrm{H}_{2}$ $\mathrm{mol}^{-1} \mathrm{CH}$ ) and butyric-acetic acid (BuH/AcH) ratio. When calculating $\mathrm{HY}$, total $\mathrm{CH}$ concentrations measured using the phenol-sulfuric method $\left(\mathrm{mg} \mathrm{L}^{-1}\right)$ were converted to mol $\mathrm{CH}$ $\mathrm{L}^{-1}$ using the molar mass of sucrose $\left(342 \mathrm{~g} \mathrm{~mol}^{-1}\right)$ as a reference, according to Ferraz Jr. et al. [11-13].

\section{Results and discussion}

Continuous $\mathrm{BioH}_{2}$ production was maintained for the entire operating period as depicted in Fig. 2. Although unstable periods and decreasing patterns may be observed (Fig. 2), hydrogenogenic activity was recovered by applying the proper operational strategies to the APBR. The main events associated with performance losses in the APBR included [i] reductions in the OLR applied to the reactor and [ii] compositional variations in the stillage during the sugarcane season, which directly affected the effluent $\mathrm{pH}$ of the reactor. A combination of strategies was carefully assessed in an attempt to enhance the hydrogenogenic activity in the APBR, and the performance of the reactor in relation to each strategy is discussed herein.

\section{Periodic discharge of excess biomass}

Stable $\mathrm{BioH}_{2}$ production was observed during the 45 first days of operation, which led to average VHPR (Fig. 2a) and MHFR (Fig. 2b) values of $1203 \mathrm{~mL} \mathrm{H}_{2} \mathrm{~L}^{-1} \mathrm{~d}^{-1}$ and $6.03 \mathrm{mmol} \mathrm{H}_{2} \mathrm{~h}^{-1}$, respectively (Table 1 ), although a slight decline in hydrogen production was subsequently observed. This declining pattern was most likely related to the biomass aging, which is characterized by the proliferation of non-hydrogen producing bacteria. In a previous study [12], $\mathrm{BioH}_{2}$ production decreased to negligible levels at approximately 50-60 days of operation in an APBR under similar operating conditions to those used in this study. Because negative effects of biomass accumulation 


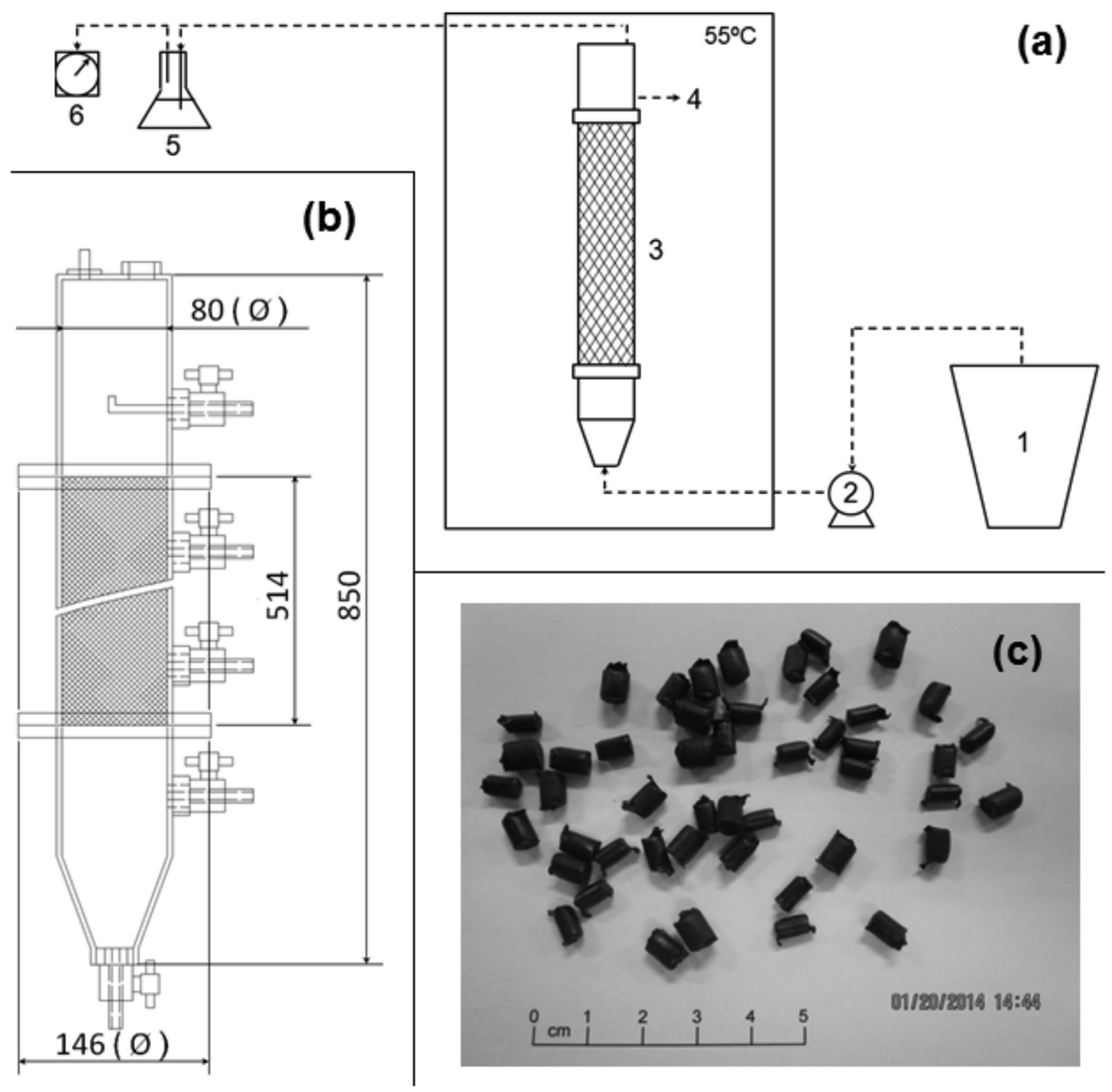

Fig. 1 - Diagram of the acidogenic system: (a) experimental apparatus, (b) reactor characteristics (measurements in millimeters), and (c) support material (LDPE) used in the packed bed. Legend: 1 - reservoir; 2 - peristaltic pump; 3 - APBR; 4 - effluent outlet; 5 - water seal; 6 - gas meter.

have been reported $[2,24,25]$ over the $\mathrm{BioH}_{2}$ production, a biomass discharge was conducted here (Fig. 2c, discharge \#1, day $51,350 \mathrm{~mL}$ or $\sim 9.5 \mathrm{~g}$ VSS), in order to enhance the hydrogen production by $47 \%$ (VHPR ranging from 409 to $\left.862 \mathrm{~mL} \mathrm{H}_{2} \mathrm{~L}^{-1} \mathrm{~d}^{-1}\right)$. However, the decreasing $\mathrm{BioH}_{2}$ production trend was reestablished, so that this pattern might be related to the negative effects of biomass aging as previously described. Limitations related to the biomass discharge could also reflect such patterns because the amount of removed solids was not sufficient to provide adequate SOLR values.

Three additional biomass discharges were performed for subsequent decreases in $\mathrm{BiOH}_{2}$ production related to the application of stillages from samples $\mathrm{C} 4$ and C5 to the APBR: discharges \#2 and \#3 (1400 mL or $22.9 \mathrm{~g}$ VSS) on days 98 and 105 , respectively, and discharge \#4 (1100 mL or $20.5 \mathrm{~g} \mathrm{VSS}$ ) on day 150 as depicted in Fig. 2c. In these periods of decreasing production, significant alterations to the effluent $\mathrm{pH}$ were also measured and will be further discussed; therefore, the biomass accumulation was not the only factor affecting $\mathrm{BioH}_{2}$ production. Discharges \#2 and \#3 were associated with effluent $\mathrm{pH}$ control, and they promoted an increase in hydrogenogenic activity, thus leading to peak values of $879 \mathrm{~mL}$ $\mathrm{H}_{2} \mathrm{~L}^{-1} \mathrm{~d}^{-1}$ (VHPR, Fig. 2a) and $5.8 \mathrm{mmol} \mathrm{H}_{2} \mathrm{~h}^{-1}$ (MHFR, Fig. 2b), respectively. For discharge \#4, improvements were not observed in $\mathrm{BioH}_{2}$ production, and this poor performance was most likely related to the negative effects of $\mathrm{pH}$. The biomass discharges conducted in this study did not promote significant variations in the SOLR from that of the initial operating period (Fig. $3 b-c)$. The pattern observed for the biomass retention within the reactor indicates that the SOLR varied within a narrow range (1.5-4.0 $\mathrm{g} \mathrm{CH} \mathrm{g}^{-1} \mathrm{VSS} \mathrm{d}^{-1}$, Fig. 3b-c) for biomass concentrations higher than $5-6$ gVSS L $^{-1}$ (Fig. 3a, day 30 onwards) compared to the initial values. The low porosity caused by the random arrangement of support media in packed-bed reactors hinders the removal by bottom discharge of interstitial acidogenic biomass that accumulates in the bed, which 
may explain the pattern observed for the retention of biomass within the reactor and the variations of the SOLR during operation (Fig. 3b-c). Improved control over the SOLR may be obtained by employing additional strategies for biomass discharge, such as backwashing the reactor, or using structured-bed reactors, which combine immobilized cell growth with higher bed porosities $[39,40]$.

\section{Application of optimal and continuous OLR}

A sharp decline in hydrogen production was observed when the reactor was fed less concentrated stillage samples ( $\mathrm{TCOD}=23.4 \mathrm{~g} \mathrm{~L}^{-1}, \mathrm{CH}=3.9 \mathrm{~g} \mathrm{~L}^{-1}$, sampling C3, Fig. 2) because the applied OLR was reduced (Fig. $2 \mathrm{~b}, 50.4 \mathrm{~kg} \mathrm{COD} \mathrm{m}^{-3} \mathrm{~d}^{-1}$ ). Such organic underload stimulated methanogenic activity in the APBR (Fig. 2d), which also led to unstable $\mathrm{CH}$ conversion (Fig. 2c). However, by increasing the OLR to optimal conditions (84.2 $\mathrm{kg} \mathrm{COD} \mathrm{m}^{-3} \mathrm{~d}^{-1}$ ), increased hydrogenogenic activity was observed, which led to a VHPR of $1210 \mathrm{~mL} \mathrm{H}_{2} \mathrm{~L}^{-1} \mathrm{~d}^{-1}$ (Fig. 2a).

Yet regarding the control of the OLR as an operational strategy, a short organic overload was imposed in the APBR for approximately five days (Fig. $2 \mathrm{~b}, \sim 110 \mathrm{~kg}$ COD m $\mathrm{m}^{-3} \mathrm{~d}^{-1}$, days 160-165) after the stillages from samples $C 5$ were used to feed the reactor. This operational strategy was performed in an attempt to provide optimal SOLR conditions because hydrogenogenic activity was not enhanced by discharging the accumulated biomass (discharge \#4) or by controlling the effluent $\mathrm{pH}$. By applying an organic shock load to the reactor, VHPR and MHPR values of $888 \mathrm{~mL} \mathrm{H}_{2} \mathrm{~L}^{-1} \mathrm{~d}^{-1}$ (Fig. 2a) and $6.0 \mathrm{mmol} \mathrm{H}_{2} \mathrm{~h}^{-1}$ (Fig. 2b), respectively, were achieved. Based on the negligible variations in the SOLR after the 30th day of operation (values usually lower than $3 \mathrm{~g} \mathrm{CH} \mathrm{g}^{-1} \mathrm{VSS} \mathrm{d}^{-1}$, Fig. $3 \mathrm{~b}-\mathrm{c}$ ), which were observed even under higher OLRs, the increasing $\mathrm{BioH}_{2}$ production rates may have resulted from the hydrodynamic conditions in the reactor causing lower partial pressures of hydrogen as a result of increasing upflow velocities. The upflow velocity rose approximately $30 \%$ in the APBR by increasing the OLR from 84.2 to $110 \mathrm{~kg}$ COD m$^{-3} \mathrm{~d}^{-1}$. The subsequent reduction of the OLR to optimal values (Fig. $2 \mathrm{~b}, 84.2 \mathrm{~kg} \mathrm{COD} \mathrm{m}^{-3} \mathrm{~d}^{-1}$ ) led to further decreases in $\mathrm{BioH}_{2}$ production, which were most likely associated with the high effluent $\mathrm{pH}(\sim 5.3)$.

Although the use of organic overloading to recover hydrogenogenic activity constitutes an efficient strategy, such conditions must be imposed in the reactor over short periods because previous studies [11] have indicated that performance losses occur by applying OLRs higher than $100 \mathrm{~kg} \mathrm{COD} \mathrm{m}^{-3} \mathrm{~d}^{-1}$ in acidogenic systems using sugarcane stillage as the substrate. Moreover, the application of organic overloads by increasing the wastewater flow rate may cause a biomass washout in suspended-growth systems (e.g., CSTR tanks); thus, the use of such a strategy may only be adequate in immobilized-cell reactors because the packed bed acts as a barrier that hinder solids wash out.

\section{Control of the effluent $\mathrm{pH}$}

The effluent $\mathrm{pH}$ played a key role in obtaining high and continuous $\mathrm{BioH}_{2}$ production because the SOLR could not be properly controlled by discharging the biomass. The optimal conditions for $\mathrm{BioH}_{2}$ production were associated with effluent
$\mathrm{pH}$ values in the range of 5.1-5.2 (Table 1). Severe negative impacts on $\mathrm{BioH}_{2}$ production were observed when the effluent $\mathrm{pH}$ values were lower than 5.0 (100 days, C4, Fig. 2e) and higher than 5.3 (days 160-170, C5, Fig. 2e), and these $\mathrm{pH}$ conditions were related to compositional variations of the raw stillage (samplings C4 to C6/7). Although significant differences in the macronutrients, micronutrients and total phenols were not observed throughout the entire sugarcane season (data not shown), the BOD/TCOD ratio estimated for stillages from samplings $C 4$ to $C 6 / 7$ decreased from 0.60 to 0.44 during the sugarcane season, indicating higher levels of nonbiodegradable compounds. The accumulation of biomass in both periods could also negatively affect $\mathrm{BioH}_{2}$ production as previously discussed. In both cases, the hydrogenogenic activity of the APBR could be recovered by increasing ( 7.5, days 115-160, Fig. 2e) or decreasing ( 6.5, days 161 to 160 ; and $\sim 5.5$, day 176 onwards, Fig. 2e) the influent $\mathrm{pH}$, thus leading to effluent $\mathrm{pH}$ values ranging from 5.1 to 5.2 , which is considered the optimal range for the $\mathrm{BioH}_{2}$ production (Table 1).

However, because the acidogenic system proved to be more resilient to reductions in $\mathrm{pH}$, a $\mathrm{pH}$ shock was applied to the APBR (Fig. 2e, day 192) by pumping in raw stillage without previous $\mathrm{pH}$ adjustment (4.4). This strategy was performed in an attempt to generate a disturbance in the acidogenic system to reproduce conditions similar to that observed at the end of the inoculation step by natural fermentation, when the $\mathrm{pH}$ measured in the acidified stillage was $\sim 4.5$. Although this strategy caused an abrupt performance loss in relation to $\mathrm{BioH}_{2}$ production (Fig. 2a-c) and $\mathrm{CH}$ conversion (Fig. 2c), hydrogenogenic activity was satisfactorily recovered, which led to peak values of $2107 \mathrm{~mL} \mathrm{H}_{2} \mathrm{~L}^{-1} \mathrm{~d}^{-1}$ (VHPR, Fig. 2a and Table 1) and $14 \mathrm{mmol} \mathrm{H}_{2} \mathrm{~h}^{-1}$ (MHFR, Fig. $2 \mathrm{~b}$ and Table 1). Furthermore, the system presented a stable performance by the end of the operation, reaching patterns of VHPR and MHFR that were similar to better than the conditions of the initial period of operation (VHPR of $1604 \mathrm{~mL} \mathrm{H}_{2} \mathrm{~L}^{-1} \mathrm{~d}^{-1}$, Fig. 2a and Table 1; and MHFR of $6.03 \mathrm{mmol} \mathrm{H}_{2} \mathrm{~h}^{-1}$, Fig. $2 \mathrm{~b}$ and Table 1).

\section{Overall performance}

The HY values (Fig. 2c) presented similar patterns to that of the VHPR and MHFR, leading to an average value of $3.7 \mathrm{~mol} \mathrm{H}_{2}$ $\mathrm{mol}^{-1} \mathrm{CH}$ at the initial stable phase (days $1-85$, excluding the unstable period related to the organic underload), and peaking at $5.6 \mathrm{~mol} \mathrm{H}_{2} \mathrm{~mol}^{-1} \mathrm{CH}$ after the $\mathrm{pH}$ shock was imposed in the reactor. Such values are considerably higher than those reported in Ferraz Jr. et al. (2014), who observed $2.4 \mathrm{~mol} \mathrm{H}_{2} \mathrm{~mol}^{-1}$ $\mathrm{CH}$ at an OLR of $72.4 \mathrm{~kg} \mathrm{COD} \mathrm{m}^{-3} \mathrm{~d}^{-1}$, indicating the influence of optimal OLR conditions on the operation of acidogenic systems. A comparison of the VHPR and HY at the initial and final operating periods (Table 1) shows that an opposite pattern occurred, with higher $\mathrm{HY}$ values attained at the initial phase (3.4 $\mathrm{mol} \mathrm{H}_{2} \mathrm{~mol}^{-1} \mathrm{CH}$, Table 1) and higher VHPR values obtained at the final phase (1604 $\mathrm{mL} \mathrm{H}_{2} \mathrm{~L}^{-1} \mathrm{~d}^{-1}$, Table 1$)$. This result suggests the establishment of more favorable conditions for the HPB at the initial phase because of the more efficient substrate conversion in terms of energy extraction as indicated by the higher HY values. The lower HY values observed at the end of the operation were most likely caused by the accumulation of biomass in the bed as indicated by the 

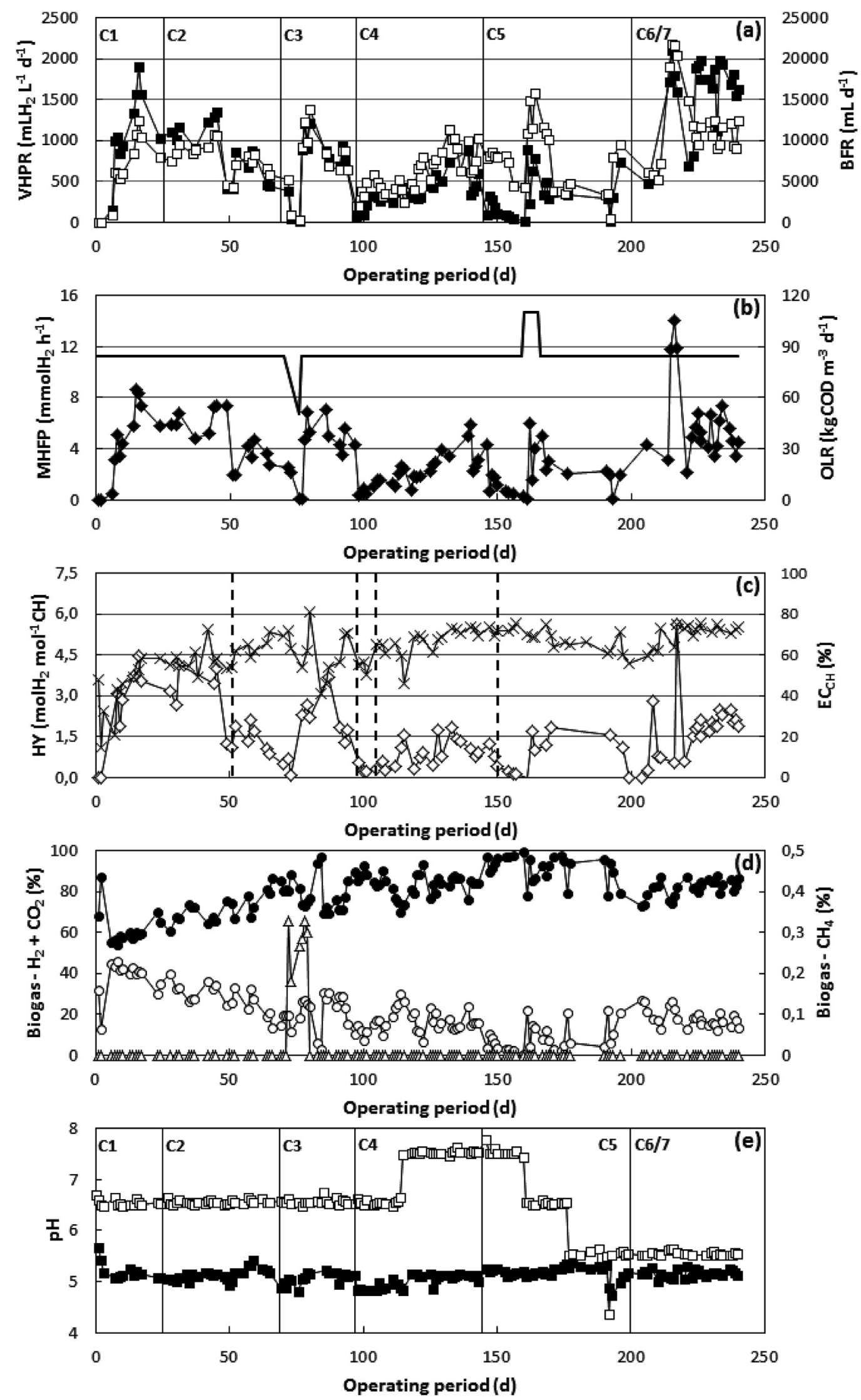

Fig. 2 - Temporal profiles of the (a) biogas flow rate (BFR, - $\square-$ ) and volumetric hydrogen production rate (VHPR, - $\square-$ ), (b) molar hydrogen flow rate (MHFR, - - ), (c) hydrogen yield (HY, $-\diamond-)$ and carbohydrate conversion (-x-), (d) biogas composition $\left(\mathrm{O}-\mathrm{H}_{2},--\mathrm{CO}_{2}, \Delta-\mathrm{CH}_{4}\right)$ and (e) influent (- $\left.\square-\right)$ and effluent (- -$)$ pH. Operational conditions: OLR ( - ) and biomass discharge (vertical dashed lines). $\mathrm{C} 1$ to $\mathrm{C} 6 / 7$ indicate the stillage sampling. 
Table 1 - APBR performance in relation to the production of biohydrogen and conversion of carbohydrates.

\begin{tabular}{|c|c|c|c|c|}
\hline \multirow[t]{2}{*}{ Response-variable } & \multirow[t]{2}{*}{ Unit } & \multicolumn{3}{|c|}{ Corresponding period } \\
\hline & & Days $7-45$ & Days 206-240 & Overall (Days 7-240) \\
\hline \multirow[t]{2}{*}{ BFR } & $\left(\mathrm{mL} \mathrm{d}^{-1}\right)$ & $8716 \pm 2257(16)$ & $11,893 \pm 4683(21)$ & $8021 \pm 3947(108)$ \\
\hline & & 12,382 & 21,849 & 21,849 \\
\hline \multirow[t]{2}{*}{$\mathrm{VHPR}^{\mathrm{a}}$} & $\left(\mathrm{mL} \mathrm{H}_{2} \mathrm{~L}^{-1} \mathrm{~d}^{-1}\right)$ & $1203 \pm 288(16)$ & $1604 \pm 447(21)$ & $789 \pm 590(108)$ \\
\hline & & 1897 & 2107 & 2107 \\
\hline \multirow[t]{2}{*}{ MHFR $^{a}$} & $\left(\mathrm{mmol} \mathrm{H}_{2} \mathrm{~h}^{-1}\right)$ & $6.03 \pm 1.59(16)$ & $6.03 \pm 3.07(21)$ & $3.82 \pm 2.63(108)$ \\
\hline & & 8.63 & 14.07 & 14.07 \\
\hline \multirow[t]{6}{*}{$\mathrm{HY}^{\mathrm{a}}$} & $\left(\mathrm{mol} \mathrm{H}_{2} \mathrm{~mol}^{-1} \mathrm{CH}\right)$ & $3.4 \pm 0.7(16)$ & $1.9 \pm 1.1(18)$ & $1.5 \pm 1.1(99)$ \\
\hline & & 4.5 & 5.6 & 5.6 \\
\hline & $\left(\mathrm{mol} \mathrm{H} \mathrm{g}^{-1} \mathrm{CODr}\right)^{\mathrm{b}}$ & $8.0 \pm 3.1(16)$ & $5.2 \pm 2.7(18)$ & $4.1 \pm 3.0(99)$ \\
\hline & & 11.7 & 14.6 & 14.6 \\
\hline & $\left(\mathrm{mol} \mathrm{H} \mathrm{g}^{-1} \mathrm{CODa}\right)^{\mathrm{c}}$ & $0.87 \pm 0.37(12)$ & $0.72 \pm 0.23(15)$ & $0.49 \pm 0.33(85)$ \\
\hline & & 1.29 & 1.09 & 1.29 \\
\hline \multirow[t]{2}{*}{$\mathrm{H}_{2}$ (biogas) } & $(\%)$ & $37.0 \pm 6.1(16)$ & $17.5 \pm 3.7(21)$ & $19.6 \pm 10.5(108)$ \\
\hline & & 46.2 & 26.0 & 46.2 \\
\hline \multirow[t]{2}{*}{$\mathrm{EC}_{\mathrm{CH}}$} & $(\%)$ & $52.3 \pm 10.9(16)$ & $70.5 \pm 4.9(18)$ & $63.6 \pm 9.9(99)$ \\
\hline & & 72.2 & 75.6 & 81.0 \\
\hline \multirow[t]{2}{*}{$\mathrm{VSSe}^{\mathrm{d}}$} & $\left(\mathrm{mg} \mathrm{L}^{-1}\right)$ & $1138 \pm 226(11)$ & $1364 \pm 503(14)$ & $1167 \pm 330(64)$ \\
\hline & & 1500 & 1963 & 1963 \\
\hline \multirow[t]{2}{*}{$\mathrm{pH}^{\mathrm{e}}$} & $(-)$ & $5.1 \pm 0.1(26)$ & $5.2 \pm 0.1(25)$ & $5.1 \pm 0.3(159)$ \\
\hline & & 5.2 & 5.3 & 5.4 \\
\hline \multicolumn{5}{|c|}{$\begin{array}{l}\text { Notes: Data between parentheses indicate the number of samp } \\
\text { period. Data collected between days } 1 \text { and } 6 \text { of operation were } n \\
\text { a Standard temperature and pressure conditions }\left(0^{\circ} \mathrm{C} \text { and } 1 \text { atn }\right. \\
\text { b CODr }=\text { removed COD based on a ratio of } 1.12 \mathrm{~g} \mathrm{COD} \mathrm{g}{ }^{-1} \mathrm{CH} \text {. } \\
\text { c CODa = influent TCOD. } \\
\text { d VSS }=\text { VSS concentration in the effluent. } \\
\text { e Effluent pH. }\end{array}$} \\
\hline
\end{tabular}

negligible variations in the SOLR (Fig. $3 b-c)$. However, this result also indicates the feasibility of obtaining continuous hydrogen production even under unfavorable SOLR conditions as a result of the application of proper operational strategies, particularly $\mathrm{pH}$ adjustments.

Regarding the conversion of total $\mathrm{CH}$ (Fig. 2c), under increasing/continuous $\mathrm{BioH}_{2}$ production, the conversion values were usually higher than $70 \%$ (Table 1), whereas the average value obtained for the entire operating period was $63.6 \%$ (Table 1). This value is similar to the one reported by Braga et al. [32] - 63.4-63.8\%, considering the operation of an upflow sludge blanket reactor (HRT $=6-12 \mathrm{~h}$ ) fed with sucrose-based synthetic wastewater under thermophilic conditions $\left(55^{\circ} \mathrm{C}\right)$. Ferraz Jr. et al. [11,12] reported $\mathrm{CH}$ conversion levels ranging from 67.3 to $79.4 \%$, which are consistent with the values obtained in this study. Furthermore, such values are considerably higher than the ones reported in Santos et al. [14-16], in which the application of AFBRs to sugarcane stillage led to $\mathrm{CH}$ conversion efficiencies ranging from 23.3 to $52.2 \%$. Such discrepancies most likely resulted from the operation of the AFBR under organic overloads - OLR usually higher than $100 \mathrm{~kg} \operatorname{COD~m^{-3}} \mathrm{d}^{-1}$ because of the negative effects related to the excess of substrate, accumulation of acids and overload of toxic compounds, such as potassium and phenols $[9,11,14,16,28]$.

The lower VHPR (762 $\mathrm{mL} \mathrm{H}_{2} \mathrm{~L}^{-1} \mathrm{~d}^{-1}$ ) and HY (1.6 mol $\mathrm{H}_{2}$ $\mathrm{mol}^{-1} \mathrm{CH}$ ) values reported in Ferraz Jr. et al. [12] most likely resulted from an absence of effluent $\mathrm{pH}$ control because similar operational conditions to those described here were applied - in this case the effluent $\mathrm{pH}$ reached values ranging from 5.2 to 5.7, which were slightly higher than the optimal range established in this study. $\mathrm{BioH}_{2}$ production in studies based on the use of fluidized-bed reactors [14-16] indicated VHPR values considerably higher than those obtained herein. The maximum VHPR value calculated in this study $(2107 \mathrm{~mL}$ $\mathrm{H}_{2} \mathrm{~L}^{-1} \mathrm{~d}^{-1}$, Table 1) was only $27,19.5$ and $15.1 \%$ of the minimum VHPR reported in the studies of Santos et al. [14-16] respectively. However, those authors reported similar HY values to those obtained in this study. Santos et al. [15] observed $\mathrm{HY}$ values ranging from 0.19 to $0.79 \mathrm{mmol} \mathrm{H}_{2} \mathrm{~g}^{-1}$ $\mathrm{COD}_{\text {influent }}$ from raw sugarcane stillage, whereas in this study, the $\mathrm{HY}$ values calculated for the stable operating periods reached $0.72-0.87 \mathrm{mmol} \mathrm{H}_{2} \mathrm{~g}^{-1} \mathrm{COD}_{\text {influent }}$ (Table 1). The markedly opposite pattern of VHPR and HY values in fluidized-bed reactors may be directly related to maintaining low hydrogen partial pressures in such systems because of the turbulent hydrodynamic conditions that occur in AFBRs and the thermophilic temperature conditions $\left(55^{\circ} \mathrm{C}\right)$ used in the referenced studies. Such favorable conditions for HPB tend to offset the use of non-optimal operational conditions and lead to high VHPR levels even when the reactors are submitted to organic overloads.

\section{Parameters affecting hydrogen production}

Fig. 4 depicts $\mathrm{BioH}_{2}$ production in terms of VHPR and $\mathrm{HY}$ as a function of the effluent pH (Fig. 4a-b) and the SOLR (Fig. 4c-d). Peak functions, specifically the Gaussian function, were adjusted to the experimental data (Table 2) in an attempt to identify the optimal conditions of each operational parameter. 

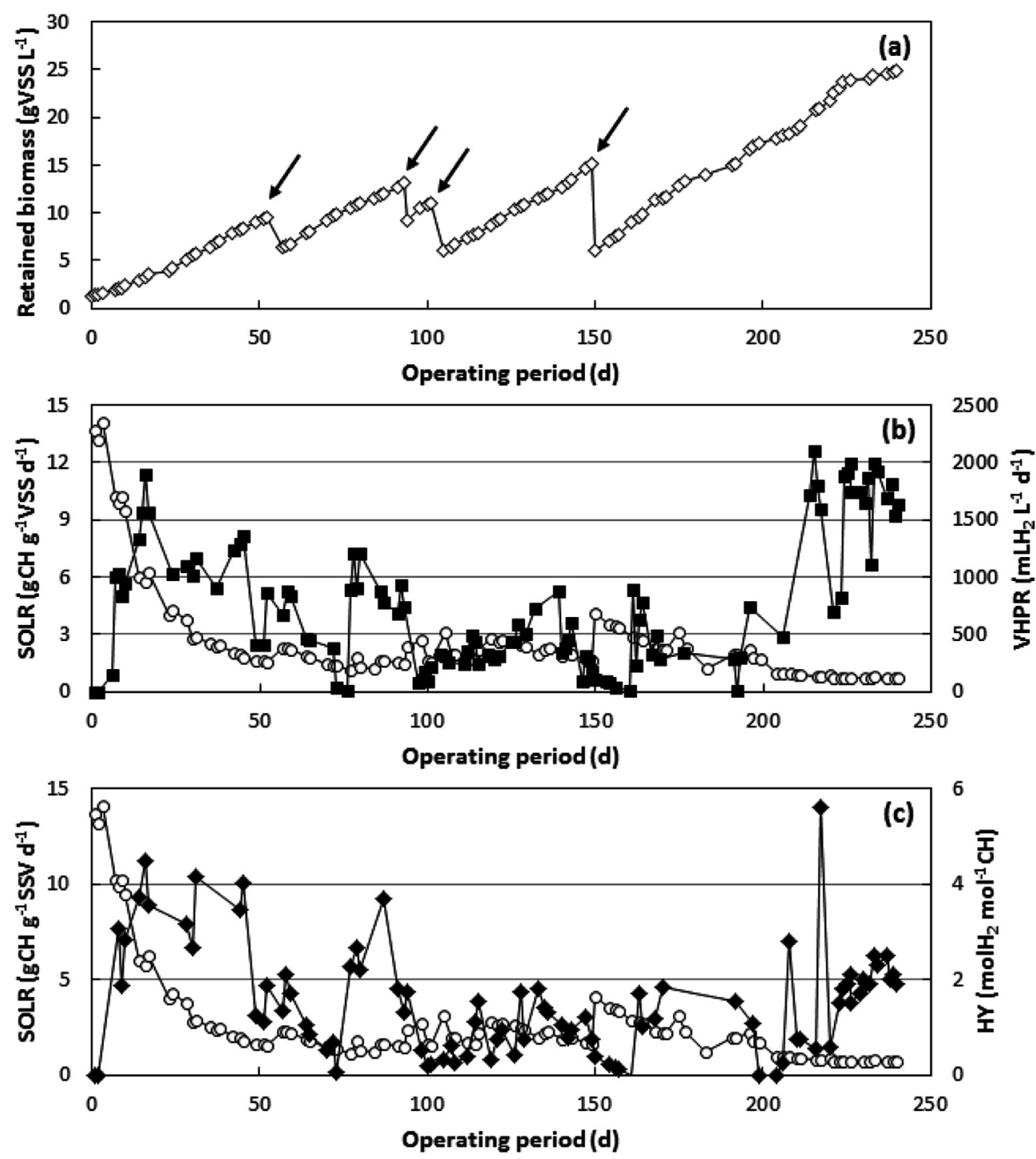

Fig. 3 - (a) Biomass retained in the reactor $\left(-\diamond_{-}\right)$and temporal profiles of the specific organic loading rate (SOLR, $\left.-O_{-}\right)$and $\mathrm{BiOH}_{2}$ production: (b) volumetric hydrogen production rate (VHPR, - - -) and (c) hydrogen yield (HY, - - -). Arrows indicate biomass discharges.

The non-linear fitting was performed using OriginPro 8 software (OriginLab Corporation, Northampton, MA, USA), employing the Levenberg-Marquardt algorithm. With respect to the effluent $\mathrm{pH}$, the optimal values estimated from the fitted functions (5.10 and 5.12, Fig. $4 a-b$ and Table 2) corresponded to the $\mathrm{pH}$ range at which the higher $\mathrm{BioH}_{2}$ experimental production rates were obtained (Table 1). The differences between the maximum values estimated for both VHPR (1559 $\mathrm{mL} \mathrm{H}_{2} \mathrm{~L}^{-1} \mathrm{~d}^{-1}$, Table 2) and HY (3.67 $\mathrm{mol} \mathrm{H}_{2} \mathrm{~mol}^{-1}$ $\mathrm{CH}$, Table 2) and the values obtained experimentally were a result of the simultaneous influence of other operational parameters, such as the influent concentration of $\mathrm{CH}$ and the SOLR. Although several optimal $\mathrm{pH}$ ranges for $\mathrm{BioH}_{2}$ production have been reported in the literature, studies on fermentative systems usually indicate decreasing or negligible $\mathrm{BioH}_{2}$ production rates for $\mathrm{pH}$ values lower than 5.0, which is consistent with the patterns observed in this study. Such performance losses may be related to inhibitory effects caused by the permeability of non-dissociated acids through the cellular membrane $[6,26,27,29]$, which usually occurs as a direct consequence of accumulated organic acids in systems operated under organic overloads [15,24,27-29]. The dissociation of such acids inside the cells promotes the release of $\mathrm{H}^{+}$ ions, and microorganisms must then redirect available energy to maintaining neutral conditions in the cytoplasm [27]. Moreover, acidic conditions negatively affect the activity of hydrogenases, which are the main enzymes for $\mathrm{BioH}_{2}$ production $[5,11,41]$. With respect to higher $\mathrm{pH}$ values (>5.3), poor production may be associated with enhancements to the propionic fermentative pathway [5,26,34], which will be further discussed, or the eventual establishment of sulfate reducing bacteria (SRB) populations in the APBR because of the high sulfate concentrations measured in the raw stillage. Certain SRB grow autotrophically on carbon dioxide using 

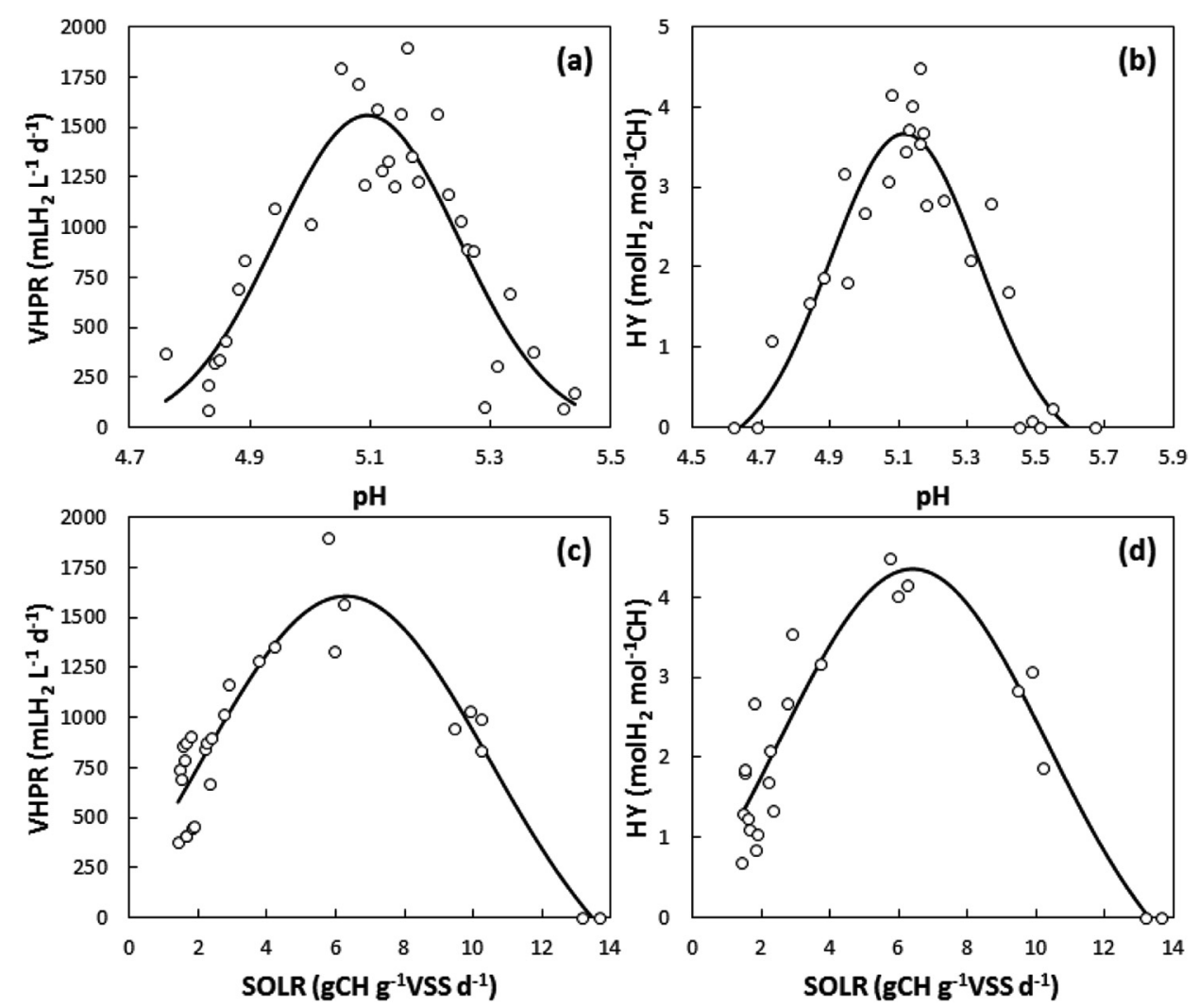

Fig. 4 - Influence of operational parameters on $\mathrm{BioH}_{2}$ production from sugarcane stillage: (a) pH vs. VHPR; (b) pH vs. HY; (c) SOLR us. VHPR (1-97 days); (d) SOLR us. HY (1-97 days). Legend: experimental points ( $\bigcirc)$, fitting curves ( - ).

molecular hydrogen as an electron donor [42]. However, several studies have associated low or negligible growth rates of SRB under acidic conditions $(\mathrm{pH}=4.0-6.0)$ and low HRT [43-46]. Lin and Chen [42] reported the inhibition of SRB under a $\mathrm{pH}$ value of 5.5 , even with sulfate concentrations of $3 \mathrm{~g} \mathrm{~L}^{-1}$ and an HRT of $12 \mathrm{~h}$. Hwang et al. [47,48] reported significant decreases in $\mathrm{BioH}_{2}$ production in acidogenic systems supplied up to $20 \mathrm{~g} \mathrm{~L}^{-1}$ of sulfate under $\mathrm{pH}$ values higher than 5.8. Based on the HRT applied to the APBR (6.0-7.5 h), the average effluent $\mathrm{pH}(\sim 5.1$, Table 1$)$ and the residual fractions of sulfate

Table 2 - Mathematical models fitted to the experimental data, optimal operating conditions and maximum estimated biohydrogen production rates.

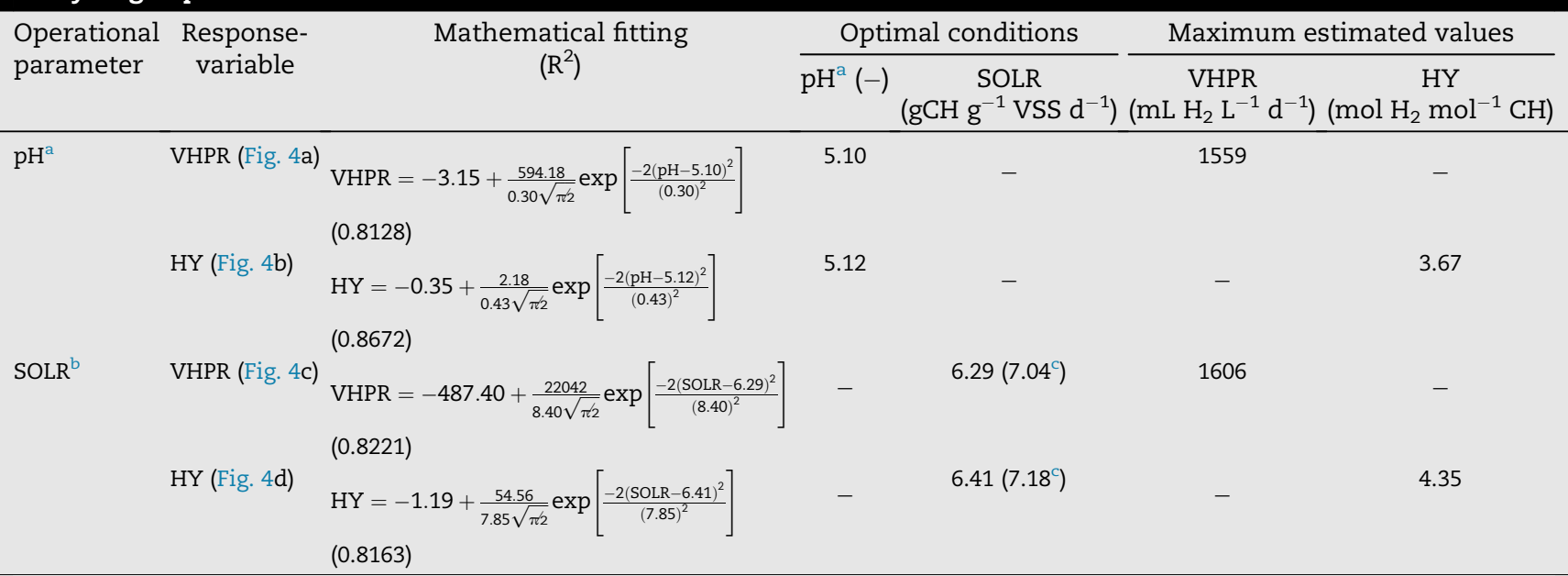

a Effluent pH (acidified stillage).

${ }^{\mathrm{b}}$ Regarding VHPR and HY values calculated for the initial operating period (1-97 days, influent $\mathrm{pH}=6.5$ ).

c $\left(\mathrm{g} \mathrm{COD} \mathrm{g}^{-1} \mathrm{VSS} \mathrm{d}^{-1}\right)$. 
in the acidified stillage (95.3\%), the influence of sulfidogenesis on the $\mathrm{BioH}_{2}$ production may be considered null in this study.

Regarding the influence of the SOLR on $\mathrm{BioH}_{2}$ production, the experimental values (VHPR and HY) were poorly correlated with SOLR based on the data from the entire operating period (data not shown). This pattern may be attributed to the modifications imposed on the APBR during the operation because the operational strategies, especially the effluent $\mathrm{pH}$ control, and the compositional variations in the raw stillage most likely promoted alterations in the acidogenic microbial community that was initially established in the reactor. However, when this analysis is restricted to the first 100 days of operation, when significant variations were not observed in the effluent $\mathrm{pH}$, the correlation graphs (Fig. 4c-d) clearly depict optimal values for the SOLR that were associated with higher $\mathrm{BiOH}_{2}$ production rates. The optimal mathematically fitted SOLR values $\left(6.29 \mathrm{~g} \mathrm{CH} \mathrm{g}^{-1} \mathrm{VSS} \mathrm{d}^{-1}\right.$ and $6.41 \mathrm{~g} \mathrm{CH} \mathrm{g}^{-1} \mathrm{VSS}$ $\mathrm{d}^{-1}$, Table 2) were similar to the values reported in the reference literature. Hafez et al. [24] associated a higher HY value to SOLR values ranging from 4.4 to $6.4 \mathrm{~g} \mathrm{COD} \mathrm{g}^{-1} \mathrm{VSS}^{-1}$, whereas in Anzola-Rojas et al. [25] higher HY values were observed for a SOLR of $6.0 \mathrm{~g} \mathrm{CH} \mathrm{g}^{-1} \mathrm{VSS} \mathrm{d}^{-1}$. With respect to the biomass yield coefficient $\left(\mathrm{Y}_{\mathrm{X} / \mathrm{S}}\right)$, the value obtained herein

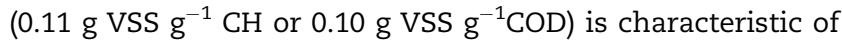
hydrogen-producing microorganisms, also reaching a level similar to those values reported by Hafez et al. [24] and Anzola-Rojas et al. [25] at favorable conditions for $\mathrm{BioH}_{2}$ production. Under excess substrate conditions (high SOLR values), the performance losses are most likely related to biomass inhibition by the substrate [24]. On the contrary, under substrate shortage conditions (low SOLR/high $\mathrm{Y}_{\mathrm{X} / \mathrm{S}}$ values), the low hydrogen production rates possibly result from alterations in the microbial metabolic pathways, so that the microorganisms use the available metabolic energy solely for cellular maintenance [25]. Another hypothesis that explains the low $\mathrm{BioH}_{2}$ production rates under low SOLR values addresses the establishment of homoacetogenic microbial populations, which also grow autotrophically on carbon dioxide by using hydrogen as the electron donor - WoodLjungdahl pathway $[12,22,25,46]$ - Reaction (1). However, the higher $\mathrm{BioH}_{2}$ production rates observed in this study could be associated with high acetic acid concentrations, which will be further discussed, suggesting that the influence of the homoacetogenic pathway could be considered negligible. In fact, several studies have indicated that the homoacetogenic pathway is inhibited in acidogenic systems operated under thermophilic conditions and low pH values $(<5.5)[10,35,49]$.

$4 \mathrm{H}_{2}+2 \mathrm{CO}_{2} \rightarrow \mathrm{CH}_{3} \mathrm{COOH}+2 \mathrm{H}_{2} \mathrm{O}$

\section{Evaluation of intermediate fermentation products}

The main fermentative pathway observed throughout the operation of the APBR consisted of the acetic-butyric acid pathway-Reactions (2) and (3), which is commonly reported in fermentative systems [11,50]. AcH and $\mathrm{BuH}$ concentrations in the effluent reached average values of $1355 \pm 717 \mathrm{mg} \mathrm{L}^{-1}$ and
$1378 \pm 925 \mathrm{mg} \mathrm{L}^{-1}$, respectively, except in the period between the 130 and 165 days of operation (Fig. 5a-b). In this case, a significant increase in the proportion of propionic acid ( $\mathrm{PrH})$ ( 25\%, Fig. 5b) was observed, which is consistent with the sharp decrease in the hydrogenogenic activity as previously indicated (Fig. $2 \mathrm{a}-\mathrm{c}$ ). The PrH concentrations measured in this study were similar to the values reported in Ferraz Jr. et al. [12], whereas the PrH concentrations reported in Santos et al. [15,16] were considerably higher at 3656 and $4267 \mathrm{mgL}^{-1}$, respectively, suggesting the operation of fluidized-bed reactors under organic overload conditions. The propionic fermentative pathway implies the consumption of available hydrogen, as presented in Reaction (4). It should be highlighted, however, that the increasing proportions of $\mathrm{PrH}$ could be related to an inhibition of the AcH fermentative pathway (Fig. 5a), since the concentrations of PrH did not vary significantly - average concentration of $721 \pm 245 \mathrm{mg} \mathrm{L}^{-1}$ (130-165 days) compared with $686 \pm 548 \mathrm{mg} \mathrm{L}^{-1}$ for the other operating periods. Such pattern is confirmed by analyzing the $\mathrm{BuH} / \mathrm{AcH}$ ratio (Fig. $5 \mathrm{c}$ ), so that increasing and/or stable hydrogen production rates were related to low $\mathrm{BuH} / \mathrm{AcH}$ ratio values $(\leq 1.0)$. The reference literature $[11,24,41]$ associates higher hydrogen production rates from $\mathrm{CH}$ with low $\mathrm{BuH} / \mathrm{AcH}$ ratios (0.3-0.9) or high $\mathrm{AcH} /$ $\mathrm{BuH}$ ratios $(>1.3)$. Thus, the results suggest that the main fermentative route associated with $\mathrm{BioH}_{2}$ production in the APBR is the acetic pathway. The high $\mathrm{BuH} / \mathrm{AcH}$ ratios observed for the $\operatorname{APBR}(>2.0)$ were usually associated with a predominance of $\mathrm{PrH}$ instead of $\mathrm{AcH}$ in the acidified stillage; therefore, the BuH fermentative pathway could not sufficiently maintain satisfactory levels of hydrogen production. As expected, the generation of more reduced metabolites, such as ethanol, butyric and lactic acid, leads to negative effects on $\mathrm{BioH}_{2}$ production, which is retained with more reduced molecules [1]. Finally, the high ethanol concentrations quantified in the effluent from the reactor between days 70 and 145 (Fig. 5a $1331 \pm 744 \mathrm{mg} \mathrm{L}^{-1}$ ) were most likely related to the higher influent ethanol concentrations in this period (samplings C3 and C4, data not shown), and not to alterations in the metabolic pathways carried out the acidogenic biomass.

Acetic acid production:

$\mathrm{C}_{6} \mathrm{H}_{12} \mathrm{O}_{6}+2 \mathrm{H}_{2} \mathrm{O} \rightarrow 2 \mathrm{CH}_{3} \mathrm{COOH}+2 \mathrm{CO}_{2}+4 \mathrm{H}_{2}$

Butyric acid production:

$\mathrm{C}_{6} \mathrm{H}_{12} \mathrm{O}_{6} \rightarrow 2 \mathrm{CH}_{3}\left(\mathrm{CH}_{2}\right)_{2} \mathrm{COOH}+2 \mathrm{CO}_{2}+2 \mathrm{H}_{2}$

Propionic acid production:

$\mathrm{C}_{6} \mathrm{H}_{12} \mathrm{O}_{6}+\mathrm{H}_{2} \rightarrow 2 \mathrm{CH}_{3} \mathrm{CH}_{2} \mathrm{COOH}+2 \mathrm{H}_{2} \mathrm{O}$

\section{Soluble phase and global COD-based mass balances}

Monitoring data obtained during the operation of the APBR were also used to calculate the COD-based mass balance for the acidogenic phase. Two distinct mass balances were calculated: the first one considered the distribution of the 

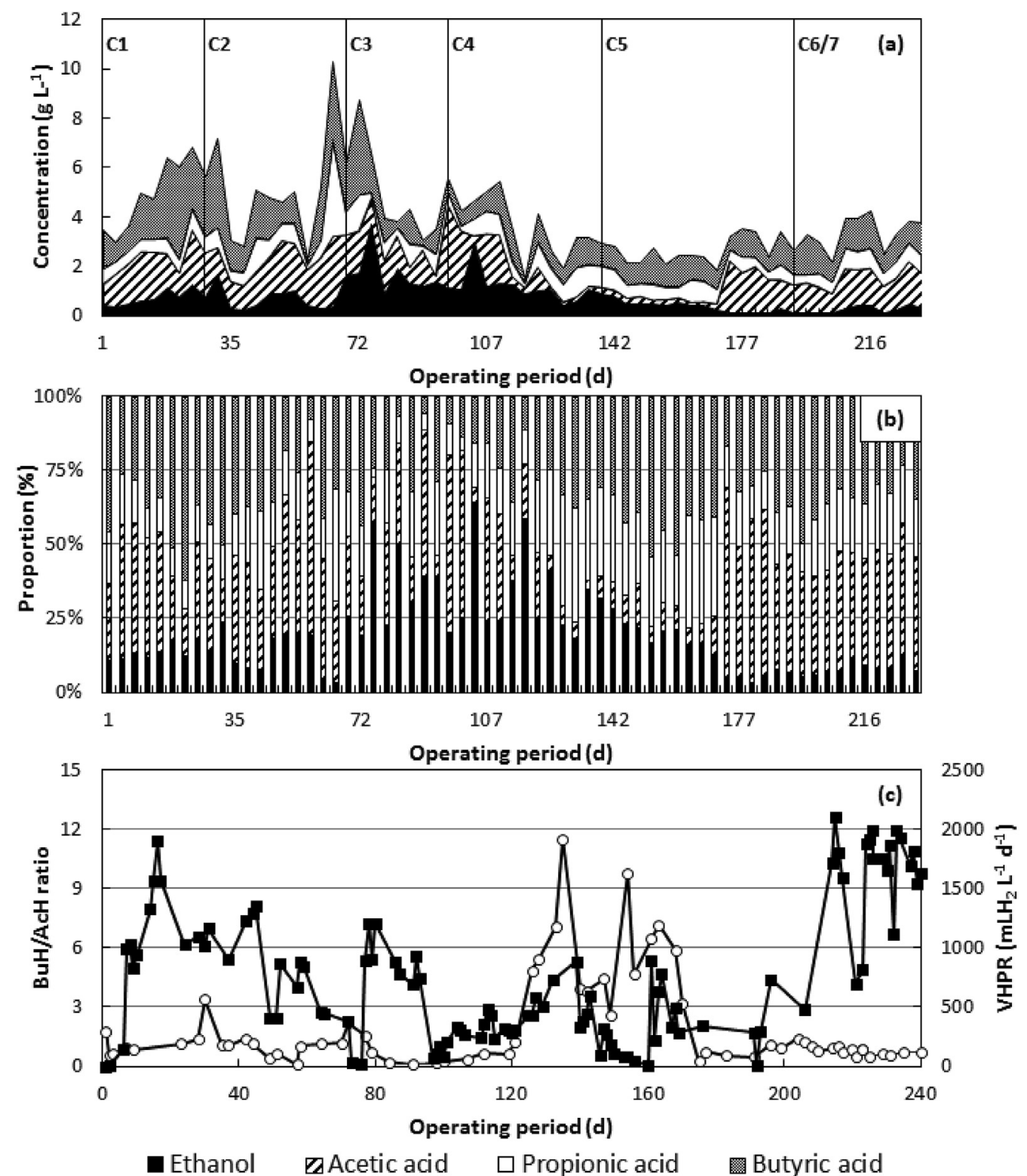

Fig. 5 - Soluble metabolites in the fermented stillage: (a) temporal profiles of the concentration; (b) proportion of metabolites, and (c) BuH/AcH ratio (- $\bigcirc-)$. Legend: VHPR (- - -); $\mathrm{C} 1$ to $\mathrm{C} 6 / 7$ indicate the stillage sampling.

soluble compounds in the raw and acidified stillage (soluble phase mass balance - SPMB), while the second one also included the production of hydrogen and suspend solids (biomass), in addition to the soluble compounds (global mass balance - GMB). Table 3 depicts the contribution of each group of analyzed compounds for the mass balances. Regarding the SPMB, the average values obtained for the raw (36.6\%) and acidified stillage (43.9\%) reached average-to-low levels, as compounds usually found in high concentrations in stillage could not be identified using the analytical methods employed, specifically the method for the determination of VFA and solvents. Such compounds primarily include melanoidins, glycerol, and lactic and succinic acids, so that studies indicate glycerol and lactic and succinic acid concentrations range, respectively, from 2.8 to $5.1 \mathrm{~g} \mathrm{~L}^{-1}$ [51,52], 4.5-12.7 $\mathrm{g} \mathrm{L}^{-1}$ [14-16,51] and 0.9-3.6 $\mathrm{g} \mathrm{L}^{-1}[14,15]$ in stillages from sugarcane and corn. Nevertheless, the results specifically regarding the SPMB for the acidified stillage are similar to the values reported in Ferraz Jr. et al. [11-13], which ranged from 37.3 to $53.2 \%$. Focusing on the results presented herein, the higher recovery levels associated with the SPMB in the acidified stillage (Table 3) result from the higher concentrations of metabolites measured in the effluent, based on the conversion of compounds that were not identified in the raw stillage to organic acids and ethanol. With respect to the GMB, the ratio between the TCOD estimated and the TCOD measured led to an average value of $82.9 \%$ (Table 3), slightly higher than the values of $66.4-78.9 \%$ reported in Ferraz Jr. et al. [11,12]. The 
Table 3 - Soluble phase and global COD-based mass balances for the acidogenic phase.

\begin{tabular}{|c|c|c|c|c|c|c|c|}
\hline \multirow[t]{2}{*}{ Mass balance } & \multicolumn{7}{|c|}{ Proportion in the measured COD (\%) } \\
\hline & Carbohydrates & Metabolites $^{a}$ & $\begin{array}{l}\text { SCOD } \\
\text { effluent }\end{array}$ & Hydrogen & $\begin{array}{c}\text { VSS } \\
\text { effluent }\end{array}$ & $\begin{array}{l}\text { Recovered } \\
\text { fraction }^{\mathrm{b}}\end{array}$ & $\begin{array}{c}\text { Non-recovered } \\
\text { fraction }\end{array}$ \\
\hline SPMB (raw stillage) & $24.1 \pm 4.5$ & $12.5 \pm 6.7$ & - & - & - & $36.6 \pm 6.7$ & $63.4 \pm 8.4$ \\
\hline SPMB (acidified stillage) & $10.1 \pm 3.1$ & $33.9 \pm 12.2$ & - & - & - & $43.9 \pm 12.4$ & $56.1 \pm 12.4$ \\
\hline $\mathrm{GMB}^{\mathrm{C}}$ & - & - & $75.0 \pm 8.4$ & $0.5 \pm 0.4$ & $7.4 \pm 3.8$ & $82.9 \pm 7.9$ & $17.1 \pm 7.9$ \\
\hline
\end{tabular}

soluble organic fraction used in this calculation was based on the values of the SCOD measured in the acidified stillage, as the analytical methods employed herein could not provide a satisfactory estimate of the soluble fraction found in stillage. $\mathrm{BioH}_{2}$ production constituted only $0.5 \%$ of the TCOD influent to the APBR (Table 3), whereas VSS production accounted for $7.4 \%$ (Table 3). This value is considerably lower than the one associated with VSS production in mesophilic systems (19.7\%), based on data reported in Ferraz Jr. et al. [13] used to corroborate the expected lower biomass growth rates in acidogenic thermophilic systems. Finally, the non-identified COD fraction regarding the GMB (17.1\%, Table 3) may also result from experimental errors and hydrogen losses due to its retention in the packed bed as a direct consequence of the biomass accumulation.

\section{Conclusions}

The results presented here indicate that acidogenic systems can recover from performance losses regardless of the cause, and they can maintain continuous hydrogen production rates over long-term operating periods when operational strategies are properly established, including [i] the periodic discharge of accumulated biomass, [ii] the continuous control of effluent $\mathrm{pH}$, and [iii] the application of a high and continuous organic loading rate to the systems. By applying a combination of these strategies, peak values of $2107 \mathrm{~mL} \mathrm{H}_{2} \mathrm{~L}^{-1} \mathrm{~d}^{-1}$ and $14 \mathrm{mmol} \mathrm{H}_{2}$ $\mathrm{h}^{-1}$ were obtained for the VHPR and MHFR, respectively, which were significantly higher than that of previous studies investigating the application of packed-bed reactors to the treatment of sugarcane stillage. $\mathrm{pH}$ proved to be a key factor for obtaining high and continuous hydrogen production, and the optimal results were observed for effluent $\mathrm{pH}$ values in the range of 5.1-5.2. The SOLR could not be properly controlled in this study because the biomass discharges did not efficiently remove the interstitial solids retained within the packed bed. However, data from the first 100 days of operation indicated an optimal SOLR of 6.3-6.4 $\mathrm{g} \mathrm{CH} \mathrm{g}^{-1}$ VSS $\mathrm{d}^{-1}$, which is consistent with previous studies on hydrogen production from fermentative systems. The selection of proper operational strategies also proved to be feasible to overcome the biomass aging, which is considered one of the main limitations of acidogenic systems most studies based on the use of acidogenic packed-bed reactors have collapsed within 50-60 days of operation, whereas the system studied herein maintained continuous $\mathrm{BioH}_{2}$ production for 240 days. Finally, additional studies should be conducted with other reactor configurations, especially structured-bed reactors because of their potential applications for $\mathrm{BiOH}_{2}$ production and improved control over the SOLR.

\section{Acknowledgments}

The authors are grateful to the São Paulo Research Foundation (FAPESP - grant numbers 2009/15984-0 and 2012/15606-9) for supporting the development of this study and to Mr. Claudio Frazão Araújo and Ms. Michele Fernanda Pires from Usina São Martinho for providing the sugarcane stillage samples used in this study.

\section{R E F E R E N C E S}

[1] Fernandes BS, Peixoto G, Albrecht FR, del Aguila NKS, Zaiat M. Potential to produce biohydrogen from various wastewaters. Energy Sustain Dev 2010;14:143-8.

[2] Peixoto G, Saavedra NK, Varesche MB, Zaiat M. Hydrogen production from soft-drink wastewater in an upflow anaerobic packed-bed reactor. Int J Hydrogen Energy 2011;36:8953-66.

[3] Show KY, Lee DJ, Tay JH, Lin CY, Chang JS. Biohydrogen production: current perspectives and the way forward. Int J Hydrogen Energy 2012;37:15616-31.

[4] Perna V, Castelló E, Wenzel J, Zampol C, Fontes Lima DM, Borzacconi L, et al. Hydrogen production in an upflow anaerobic packed bed reactor used to treat cheese whey. Int J Hydrogen Energy 2013;38:54-62.

[5] Dareioti MA, Vavouraki AI, Kornaros M. Effect of $\mathrm{pH}$ on the anaerobic acidogenesis of agroindustrial wastewaters for maximization of bio-hydrogen production: a lab-scale evaluation using batch tests. Bioresour Technol 2014;162:218-27.

[6] van Ginkel SW, Oh SE, Logan BE. Biohydrogen gas production from food processing and domestic wastewaters. Int $\mathrm{J}$ Hydrogen Energy 2005;30:1535-42.

[7] Scoma A, Bertin L, Fava F. Effect of hydraulic retention time on biohydrogen and volatile fatty acids production during acidogenic digestion of dephenolized olive mill wastewaters. Biomass Bioenerg 2013;48:51-8.

[8] Li J, Zheng G, He J, Chang S, Qin Z. Hydrogen-producing capability of anaerobic activated sludge in three types of fermentations in a continuous stirred-tank reactor. Biotechnol Adv 2009;27:573-7. 
[9] Buitrón G, Carvajal C. Biohydrogen production from Tequila vinasses in an anaerobic sequencing batch reactor: effect of initial substrate concentration, temperature and hydraulic retention time. Bioresour Technol 2010;101:9071-7.

[10] Luo G, Xie L, Zhou Q, Angelidaki I. Enhancement of bioenergy production from organic wastes by two-stage anaerobic hydrogen and methane production process. Bioresour Technol 2011;102:8700-6.

[11] Ferraz Jr ADN, Wenzel J, Etchebehere C, Zait M. Effect of organic loading rate on hydrogen production from sugarcane vinasse in thermophilic acidogenic packed bed reactors. Int J Hydrogen Energy 2014;39:16852-62.

[12] Ferraz Jr ADN, Etchebehere C, Zait M. High organic loading rate on thermophilic hydrogen production and metagenomic study at an anaerobic packed-bed reactor treating a residual liquid stream of a Brazilian biorefinary. Bioresour Technol 2015;186:81-8.

[13] Ferraz Jr ADN, Etchebehere C, Zait M. Mesophilic hydrogen production in acidogenic packed-bed reactors (APBR) using raw sugarcane vinasse as substrate: influence of support materials. Anaerobe 2015;34:94-105.

[14] Santos SC, Rosa PFR, Sakamoto IK, Varesche MBA, Silva EL. Continuous thermophilic hydrogen production and microbial community analysis from anaerobic digestion of diluted sugar cane stillage. Int J Hydrogen Energy 2014;39:9000-11.

[15] Santos SC, Rosa PFR, Sakamoto IK, Varesche MBA, Silva EL. Hydrogen production from diluted and raw sugarcane vinasse under thermophilic anaerobic conditions. Int J Hydrogen Energy 2014;39:9599-610.

[16] Santos SC, Rosa PFR, Sakamoto IK, Varesche MBA, Silva EL. Organic loading rate impact on biohydrogen production and microbial communities at anaerobic fluidized thermophilic bed reactors treating sugarcane stillage. Bioresour Technol 2014;159:55-63.

[17] Fuess LT, Garcia ML. Implications of stillage land disposal: a critical review on the impacts of fertigation. J Environ Manage 2014;145:210-29.

[18] Karlsson A, Vallin L, Ejlertsson J. Effects of temperature, hydraulic retention time and hydrogen extraction rate on hydrogen production from the fermentation of food industry residues and manure. Int J Hydrogen Energy 2008;33:953-62.

[19] Han W, Wang B, Zhou Y, Wang D, Wang Y, Yue L, et al. Fermentative hydrogen production from molasses wastewater in a continuous mixed immobilized sludge reactor. Bioresour Technol 2012;110:219-23.

[20] Fernandes BS, Saavedra NK, Maintinguer SI, Sette LD, Oliveira VM, Varesche MBA, et al. The effect of biomass immobilization support material and bed porosity on hydrogen production in an upflow anaerobic packed-bed bioreactor. Appl Biochem Biotechol 2013;170:1348-66.

[21] Lima DMF, Zaiat M. The influence of the degree of backmixing on hydrogen production in an anaerobic fixed-bed reactor. Int J Hydrogen Energy 2012;37:9630-5.

[22] Lima DMF, Moreira WK, Zaiat M. Comparison of the use of sucrose and glucose as substrate for hydrogen production in an upflow anaerobic fixed-bed reactor. Int J Hydrogen Energy 2013;38:15074-83.

[23] Penteado ED, Lazaro CZ, Sakamoto IK, Zaiat M. Influence of seed sludge and pretreatment method on hydrogen production in packed-bed anaerobic reactors. Int J Hydrogen Energy 2013;38:6137-45.

[24] Hafez H, Nakhla G, Naggar HE, Elbeshbishy E, Baghchehsaraee B. Effect of organic loading on a novel hydrogen bioreactor. Int J Hydrogen Energy 2010;35:81-92.
[25] Anzola Rojas MP, Fonseca SG, Silva CC, Oliveira VM, Zaiat M. The use of the carbon/nitrogen ration and specific organic loading rate as tools for improving biohydrogen production in fixed-bed reactors. Biotechnol Rep 2015;5:46-54.

[26] Antonopoulou G, Gavala HN, Skiadas IV, Lyberatos G. Influence of $\mathrm{pH}$ on fermentative hydrogen production from sweet sorghum extract. Int J Hydrogen Energy 2010;35:1921-8.

[27] Infantes D, González del Campo A, Villaseñor J, Fernández FJ. Influence of $\mathrm{pH}$, temperature and volatile fatty acids on hydrogen production by acidogenic fermentation. Int $J$ Hydrogen Energy 2011;36:15595-601.

[28] Searmsirimongkol P, Rangsunvigit P, Leethochawalit M, Chavadej S. Hydrogen production from alcohol distillery wastewater containing high potassium and sulfate using anaerobic sequencing batch reactor. Int J Hydrogen Energy 2011;36:12810-21.

[29] Hallenbeck PC. Fermentative hydrogen production: principles, progress, and prognosis. Int J Hydrogen Energy 2009;34:7379-89.

[30] Show KY, Lee DJ, Chang JS. Bioreactor and process design for biohydrogen production. Bioresour Technol 2011;102:8524-33.

[31] Pawar SS, van Niel EWJ. Thermophilic biohydrogen production: how far are we? Appl Microbiol Biotechnol 2013;97:7999-8009.

[32] Braga AFM, Ferraz Jr ADN, Zaiat M. Thermophilic biohydrogen production using a UASB reactor: performance during long-term operation. J Chem Technol Biotechnol 2015. http://dx.doi.org/10.1002/jctb.4665.

[33] Ferraz Jr ADN, Zaiat M, Guta M, Elbeshbjshy E, Hafez H, Nakhlab G. Impact of organic loading rate on biohydrogen production in an up-flow anaerobic packed bed reactor (UAnPBR). Bioresour Technol 2014;164:371-9.

[34] Leite J, Fernandes BS, Pozzi E, Barboza M, Zaiat M. Application of an anaerobic packed-bed bioreactor for the production of hydrogen and organic acids. Int J Hydrogen Energy 2008;33:579-86.

[35] Akutsu Y, Li YY, Harada H, Yu HQ. Effects of temperature and substrate concentration on biological hydrogen production from starch. Int J Hydrogen Energy 2009;34:2558-66.

[36] APHA, AWWA, WEF. Standard methods for the examination of water and wastewater. 21st ed. Washington D.C.: APHA; 2005.

[37] Dubois SM, Gilles KA, Hamilton JK, Rebers PA, Smith F. Colorimetric methods for determination of sugar and related substance. Anal Chem 1956;228:13-21.

[38] Adorno MAT, Hirasawa JS, Varesche MBA. Development and validation of two methods to quantify volatile acids (C2-C6) by GC/FID: headspace (automatic and manual) and liquidliquid extraction (LLE). AJAC 2014;5:406-14.

[39] Camiloti PR, Mockaitis G, Rodrigues JAD, Damianovic MHRZ, Foresti E, Zaiat M. Innovative anaerobic bioreactor with fixed-structured bed (ABFSB) for simultaneous sulfate reduction and organic matter removal. J Chem Technol Biotechnol 2014;89:1044-50.

[40] Mockaitis G, Pantoja JLR, Rodrigues JAR, Foresti E, Zaiat M. Continuous anaerobic bioreactor with a fixed-structure bed (ABFSB) for wastewater treatment with low solids and low applied organic loading content. Bioprocess Biosyst Eng 2014;37:1361-8.

[41] Khanal SK, Chen WH, Li L, Sung S. Biological hydrogen production: effects of $\mathrm{pH}$ and intermediate products. Int $\mathrm{J}$ Hydrogen Energy 2004;29:1123-31.

[42] Lin CY, Chen HP. Sulfate effect on fermentative hydrogen production using anaerobic mixed microflora. Int J Hydrogen Energy 2006;31:953-60.

[43] Reis MAM, Gonçalves LMD, Carrondo MJT. Sulphate removal in acidogenic phase anaerobic digestion. Environ Technol 1988;9:775-84. 
[44] Reis MAM, Lemos PC, Martins MJ, Costa PC, Gonçalves LMD, Carrondo MJT. Influence of sulfates and operational parameters on volatile fatty acids concentration profile in acidogenic phase. Bioprocess Eng 1991;6:145-51.

[45] Fortin D, Davis B, Beveridge TJ. Role of Thiobacillus and sulfate-reducing bacteria in iron biocycling in oxic and acidic mine tailings. FEMS Microbiol Ecol 1996;21:11-24.

[46] Saddy NMC. Homoacetogenesis during hydrogen production by mixed cultures dark fermentation. Int J Hydrogen Energy 2013;38:13172-91.

[47] Hwang JH, Cha GC, Jeong TY, Kim DJ, Bhatnagar A, Min B, et al. Effect of COD/SO42- ratio and Fe(II) under the variable hydraulic retention time (HRT) on fermentative hydrogen production. Water Res 2009;43:3525-33.

[48] Hwang JH, Choi JA, Abou-Shanab RAI, Bhatnagar A, Min B, Song $\mathrm{H}$, et al. Effect of $\mathrm{pH}$ and sulfate concentration on hydrogen production using anaerobic mixed microflora. Int J Hydrogen Energy 2009;34:9702-10.
[49] Ghimire A, Frunzo L, Pirozzi F, Trably E, Escudie R, Lens PNL, et al. A review on dark fermentative biohydrogen production from organic biomass: process parameters and use of byproducts. Appl Energy 2015;144:73-95.

[50] Dong-Jie N, Jing-Yuan W, Bao-Ying W, You-Cai Z. Effect of Mo-containing additives on biohydrogen fermentation from cassava's stillage. Int J Hydrogen Energy 2011;36:5289-95.

[51] Ahn JH, Sang BI, Um Y. Butanol production from thin stillage using Clostridium pasteurianum. Bioresour Technol 2011;102:4934-7.

[52] Bonini MA. Cultivo heterotrófico de Aphanothece microscopica Nägeli e Chlorella vulgaris em diferentes fontes de carbono e em vinhaça (Heterotrophic cultivation of Aphanothece microscopica Nägeli and Chlorella vulgaris on different carbon sources and vinasse) [M.Sc. dissertation]. Federal University of São Carlos; 2012 [in Portuguese]. 